2009

\title{
Societies without Borders: Human Rights \& the Social Sciences, Welcome to Farshad Araghi - A Longer Title - More Issues per Volume
}

Blau

Farshad Araghi

Follow this and additional works at: https://scholarlycommons.law.case.edu/swb

Part of the Human Rights Law Commons, and the Social and Behavioral Sciences Commons

\section{Recommended Citation}

Blau \& Farshad Araghi. 2009. "Societies without Borders: Human Rights \& the Social Sciences, Welcome to Farshad Araghi - A Longer Title - More Issues per Volume." Societies Without Borders 4 (1): 1-2.

Available at: https://scholarlycommons.law.case.edu/swb/vol4/iss1/1 


\title{
Societies without Borders: Human Rights \& the Social Sciences
}

\section{Welcome to Farshad Araghi - A Longer Title - More Issues per Volume}

\author{
Judith Blau
}

The journal's new co-editor is Professor Farshad Araghi. He is the Chair of the Department of Sociology at Florida Atlantic University, and writes in the areas of Global Sociology, Social Theory, Sociology of Agriculture and Human Displacement, and World-Historical Analysis. He was a postdoctoral fellow at Fernand Braudel Center for the Study of Economies, Historical Systems, and Civilizations at Binghamton University and a visiting professor of Development Sociology at Cornell University, He has won several teaching awards, including the Outstanding Graduate Teaching Award, and the Excellence in Undergraduate Teaching Award. For the past four years he has been a co-editor of the International Journal of Sociology of Agriculture and Food. I am delighted to have Farshad as my co-editor as the journal enters its fourth year.

A sub-title has been added to make it clear that the journal is multidisciplinary and that a main theme is the universality and borderlessness of human rights. Societies embed human rights, to be sure, just as they embed all social practices, economic activities, social and political movements, revolutions, and civil conflicts. Yet human rights are often only granted to insiders - those who are rich, those who speak the same language, co-ethnics, co-nationalists. The conundrums involving distinctions of insiders vs. outsiders (insiders vs. the others or we vs. them) are wellknown to social scientists but globally they take on even more sinister aspects in today's world. Or do they? Global civil society has come into its own only within the past few decades. 
Social scientists are fully aware of contemporary global interdependencies connecting everyone on the planet, making recognition of universal rights an ethical imperative. Yet scholarly analysis of the many implications of these global interdependencies is still in its infancy. Such analysis rests on different epistemological assumptions than modernist or postmodernist ones of the twentieth century. Additionally, human rights must be sturdily local, opening up spaces for scholar-activists and for collaborations between scholars and community activists. Our journal will continue to be a place to explore these topics.

In this volume (2009) we go from 2 to 3 issues per year. We welcome your queries and submissions.

Judith Blau

Judith_Blau@unc.edu

Farshad Araghi

araghi@fau.edu 